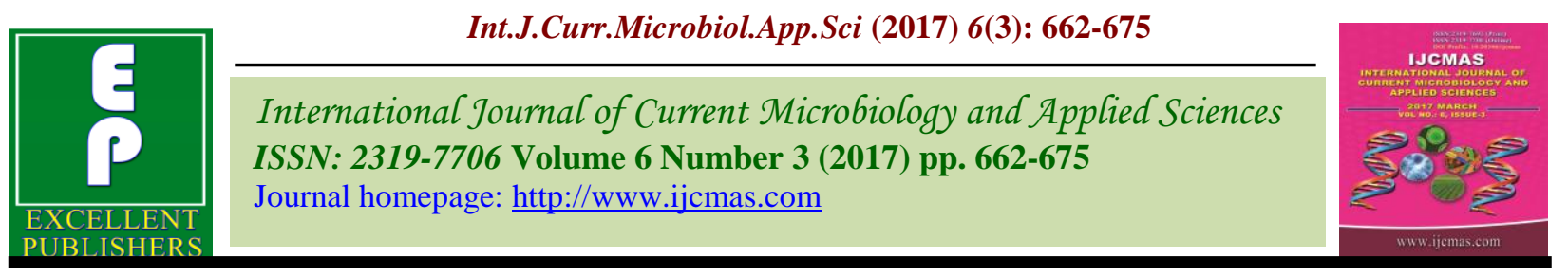

Review Article

https://doi.org/10.20546/ijcmas.2017.603.077

\title{
Heat Tolerance in Wheat - A Key Strategy to Combat Climate Change through Molecular Markers
}

\author{
Kailash Chandra*, Ravindra Prasad, Padma Thakur, \\ Kuduka Madhukar and L.C. Prasad \\ Department of Genetics and Plant Breeding, Institute of Agricultural Sciences, \\ Banaras Hindu University, Varanasi-221005, India \\ *Corresponding author
}

\section{A B S T R A C T}

\section{Keywords}

Wheat, Triticum aestivum, Heat tolerance, Terminal heat stress, Climate change, Yield, Production.

\section{Article Info}

Accepted:

15 February 2017

Available Online:

10 March 2017
Wheat (Triticum aestivum) is the second most important food crop in India only after rice and providing food for about 2 billion people which is about $36 \%$ of the world population. Annual production of wheat and rice together should be increase by $2 \mathrm{mt}$ every year in order to maintain self-sufficiency for wheat in India. The demand of wheat is projected to be $109 \mathrm{mt}$ by 2020 in India. Globally, the demand for wheat by the year 2020 is forecasted to be around $950 \mathrm{mt}$. This target will be achieved only, if the global wheat production would be increase by $2.5 \%$ per annum. This must be achieved under reduced water availability, a scenario of climate change and increasing the temperature mainly at the time of reproductive stage. The major factors behind yield plateau are different kinds of abiotic stresses which significantly restrict from expressing the full yield potential of existing wheat varieties/ genotypes and are eventually seen into reduces or stagnated the actual yield production. Major problem faced by the wheat-growing areas of South Asia is high temperature stress and terminal heat stress. Some possible ways to break the yield plateau under these kinds of abiotic stresses are to identifying the allelic sources for heat tolerance and their introgression into elite lines through conventional breeding, modern biotechnological and molecular tools are an important area for future research. A novel approach in plant breeding for tolerance to abiotic stresses is to identify the genomic reasons strongly associated with resistance/ tolerance and further utilization thereof to develop resistant/tolerant genotypes along with appreciable yield performance. Hence, this review briefly explains about to explore the updated information and tagging/mapping of genes/QTLs for heat tolerance in wheat to be used for crop improvement under breeding for mankind.

\section{Introduction}

\section{Scenario of wheat cultivation}

Wheat is one of the most important staple food crops of the world, occupying $17 \%$ of crop acreage worldwide, feeding about $40 \%$ of the world population and providing $20 \%$ of total food calories and protein in human nutrition (Gupta et al., 2008). It is considered to be the second most important food crop in India only after rice and providing foods for 
about 2 billion people which is about $36 \%$ of the total world population. In Indian subcontinent India, Nepal, Bangladesh and Pakistan are major wheat producing countries.

Wheat is cultivated over a wide area all over the world and is grown on an area of about 224.82 million hectare and production of about 732.98 million tonnes with productivity of 3.26 tonnes per hectare (Anonymous, 2015a). Half of the total cultivated area under wheat, is located in less developed countries where there have been steady increase in the productivity since green revolution, mainly through genetic improvements in yield potential (Reynolds and Borlaug, 2006). In India, wheat is grown on an area of about 30.37 million hectare which produces 90.78 million tonnes of wheat with a productivity of 2.99 tonnes per hectare (Anonymous, 2015b). However, to feed the continue increasing the population, it has been projected that yields of rice, maize, and wheat must increase by at least $70 \%$ before 2050 (Furbank and Tester, 2011).

\section{Impact of Climate Change on Wheat}

The demand of wheat is estimated to be 109 million tonnes by 2020 as stated by Nagarajan, 2005 in article "Can India produce enough wheat even by 2020?" In this context a significant progress has been made in wheat production after green revolution due to the efforts from national agricultural research system and the efforts from CIMMYT, Mexico under leadership of Dr. MS Swaminatan and father of green revolution and Novel Prize winner Dr. NE Borlaug, it is a matter of great concern that the plateau for highest yield level has been persisting since last decade. Globally, the demand for wheat by the year 2020 is forecasted to be around 950 million tonnes (Singh et al., 2011). This target will be achieved only, if global wheat production will be increased by $2.5 \%$ per annum (Singh et al., 2011). This must be achieved under reduced water availability, a scenario of climate change and increase in temperature. The major factors behind yield plateau are different kinds of abiotic stresses which restrict from expressing the actual yield potential of the cultivated wheat varieties/genotypes that eventually are observed into reduced/stagnated yield production of the crops because of stress.

The effects of global warming are being felt in India, with the most significant impact being experienced in the Eastern Gangetic Plains Zone in the form of shorter winters and the onset of significantly higher temperatures much earlier than normal. The significance of high temperature (heat) stress in limiting productivity of wheat in India was first indicated by Howard (1924) who stated that "Wheat growing in India is a gamble in temperature". This statement is valid even today (Sharma et al., 2002). The cultivation of wheat is limiting by temperature at both ends of the cropping season and high temperature stress has an adverse effect on wheat productivity. A decade ago, $40^{\circ} \mathrm{C}$ before March 30 was uncommon in the eastern Gangetic Plains. Now such temperatures occur frequently even before March 30, with $40^{\circ} \mathrm{C}$ being recorded, on average, around one week earlier than normal. Therefore, there is a new urgency to efforts to develop genotypes which are either tolerant to terminal heat stress or could mature very early and escape from the stress without yield penalty caused by heat or terminal heat stress.

\section{Heat stress a Key threat to Wheat production}

The scenario for wheat in India is undergoing the following major changes: the cool period for the wheat crop is shrinking, while the threat of terminal heat stress is increasing 
(Rane et al., 2000; Sharma et al., 2002). This makes the wheat crop vulnerable to different stresses. Major problem faced by the wheatgrowing areas of South Asia is high temperature stress, mainly terminal heat stress (Joshi et al., 2007a) and high temperature stress for wheat is defined as when the mean average temperature of the coolest month is greater than $17.5{ }^{0} \mathrm{C}$ (Fischer and Byerlee, 1991).

Both the proximity to the equator and the popular cropping systems, which involve late sowing of wheat, are the major causes of exposure of wheat in India and other neighbouring countries to high temperatures during grain filling (Tandon, 1994; Rane et al., 2000). Effect of high temperature is particularly severe during grain filling; which leads to the yield loss up to $40 \%$ under severe stress conditions (Hays et al., 2007). The heat stress is estimated to affect some $40 \%$ of irrigated wheat grown in less developed countries (Joshi et al., 2007) representing about 13.5 million hectare in India alone (Joshi et al., 2007a).

Based on some current predictions it is foresaid that by the end of this century, mean day-time temperature in South Asia would be risen by up to $4{ }^{\circ} \mathrm{C}$ (IPCC Climate and change, 2007), causing the transformation of as much as one half of the Indo-Gangetic plain into an environment which is suboptimal for wheat production (Ortiz et al., 2008). Modeling has suggested that grain yield in this area will fall by $3-17 \%$ per $1{ }^{\circ} \mathrm{C}$ increase in mean air temperature. It is therefore recommended to design a breedingled approach to adapting wheat to elevated temperature environments (Reynolds et al., 2007; Singh et al., 2007). The genetic basis of high temperature tolerance in wheat is not very well understood; to date it has been assessed largely by monitoring the response of grain yield (Yang et al., 2002; Singh and
Trethowan, 2007; Pinto et al., 2010), grain filling duration (Yang et al., 2002), grain size, canopy temperature depression (Reynolds et al., 1994; Ayeneh et al., 2002), a heat sensitivity index (Mohammadi et al., 2008; Mason et al., 2010; Paliwal et al., 2012) or various senescence-related traits (Vijayalakshmi et al., 2010) to exposure to high temperature.

The Directorate of Wheat Research, being nodal centre for wheat research in the country has been instrumental in screening of large number of wheat genotypes at hot spot locations for heat stress under AICW\&BIP network.

The major cooperating centres identified in the country for screening material for heat stress include Karnal and Hisar in NWPZ; Varanasi and Sabour in NEPZ; Indore, Jabalpur, Bilaspur, Sagar, Vijapur and Junagarh in Central zone and Dharwad, Akola and Pune in the Peninsular zone. The efforts made under coordinated system resulted in identification of sources of heat tolerance such as WH 730, CBW 12, NIAW 34, NIAW 845, RAJ 4037 and HD 2808 which are being used in breeding programme.

There is a new urgency for efforts to develop genotypes that are either tolerant to terminal heat stress or that mature early (without a yield penalty) and thus escape the stress. Wheat cultivars that have been recommended for planting under delayed sowings of the Indo-Gangetic Plains are PBW 373, RAJ 3765, and UP 2425 for the NWPZ; and, HUW 234, HUW 510, NW 1014, HW 2045, HD 2643, HP 1744, DBW 14, and NW 2036 for the NEPZ. Despite the release of a multitude of varieties over the last 20 years, HUW 234 (released in 1986) is still the dominant variety in the eastern Gangetic Plains (Joshi et al. 2007a). 
Way to Combat against Climate change with reference to wheat Heat Stress

Some possible ways to break the yield plateau under these kinds of abiotic stresses are increasing area under production along with good crop management or by developing varieties with enhanced genetic tolerance to get a required output level. Since the increase in area does not seem to be practical, the only pragmatic approach available is the utilization of genetic tolerance.

\section{Conventional Wheat heat stress breeding}

Conventional breeding aims are to screen the large genotypes and select the desirable genotype for trait of interest is only based on phenotypic observation, in order screening of wheat germplasm lines for selecting the promising heat tolerance genotype based on phenotypic data were performed through above mentioned approach during early stage. In order to exploit phenotypic selection the breeding line for heat stress must have desirable variability. Conventional breeding method like pure line, pedigree method, Bulk scheme, single seed descent method, back cross breeding has increase the yield up to 3 $\%$ (Singh and Singh, 2015). This variability were exploited by several author in order to screen their germplasm based on heat susceptibility index, membrane thermo stability, canopy temperature depression and stay-green character (Reynolds et al., 2001). Grain weight under heat stress during grain filling is a measure of heat tolerance (Tyagi et al., 2003; Singha et al., 2006). Selection based on the phenotype of the plant is influenced by environment. Hence there is an urgent need to inclusion of tools which are environmentally neutral like DNA Markers.

\section{Need of Molecular Breeding}

Identifying allelic sources for heat tolerance and their introgression into elite lines through conventional plant breeding, modern biotechnological and molecular approaches (Ortiz et al., 2008) are an important area for future research. A novel approach in plant breeding for tolerance to abiotic stresses is to identify the genomic reasons positively associated with tolerance and further utilization thereof to develop the tolerant genotype with appreciable yield performance and desirable for another ergonomical important trait as well.

To date, the extent of success in identifying genetic markers associated with terminal heat tolerance in wheat, and indeed other crop species, has been limited. Robust marker-trait associations are considered to be a prerequisite for an efficient marker-assisted breeding program (Kato et al., 2000), and these are most effectively achieved through quantitative trait locus (QTL) mapping (Patterson, 1998).

Mapping of desired genomic regions using SNP genotyping are becoming popular mainly due to their precise and high throughput results. Use of RIL populations for mapping of QTLs is considered to be highly advantageous due to the facts that multiple selfing events increase the recombination events which allow a finer mapping of QTLs. More importantly, once the RILs are established having fixed genotypes as homozygote, these lines can be repeatedly used for investigating QTLs of various phenotypes under different environments provided the parents involved were contrasting for the trait of interest.

\section{Relevant studies related to Marker assisted heat tolerance in wheat}

Yang et al., (2002) studied the genetic basis of heat tolerance in wheat using Ventnor (heat-tolerant) and Karl 92 (heat-susceptible) cross in $\mathrm{F}_{2}$ generation and found that two SSR markers namely Xgwm11 and Xgwm293, 
linked with QTLs responsible for heat tolerance and these QTLS were associated with grain filling. Whereas Mohammadi, (2004) studied the effect of post-anthesis heat stress in RILs of wheat and concluded that kernel weight and kernel weight reduction are the best measurements of heat tolerance, hence these traits can be used for studies such as quantitative trait loci mapping. Patil et al., (2008) evaluated wheat genotypes for terminal and continual heat stress tolerance and reported that the reduction in grain number in terminal heat stress environment was due to sudden increase in temperature during grain growth period.

Mason et al., (2010) identified QTL associated with heat susceptibility index (HSI) of yield components in response to a short term heat shock during early grain filling in wheat. The HSI was used as an indicator of yield stability and a proxy for heat tolerance. QTL analysis identified 15 and 12 QTLs associated with HSI. The results of this study validate the use of the main spike for detection of QTLs for heat tolerance and identify genomic regions associated with improved heat tolerance level.

Moshatati et al., (2012) reported the significant effect of sowing date, cultivars and their interaction on yield and other traits. Highest grain yield (5.949 t/ha) were produced in sowing dates of $6^{\text {th }}$ December consider timely sown and the lowest grain yield (1.690 t/ha) was produced in sowing dates of $4^{\text {th }}$ February which is consider very late.

Garg et al., (2012) envisaged the involvement of a complex phenomenon including a number of physiological and biochemical changes for terminal heat stress tolerance and these are governed by multiple genes. They explained $29.89 \%$ and $24.14 \%$ phenotypic variation for grain weight per spike and thousand grain weight respectively based on the single marker analysis. One SNP molecular marker was detected between heat tolerant genotype (K7903) and heat susceptible genotype (RAJ4014) and the analysis of amino acid sequence showed that the base transition $(\mathrm{A} / \mathrm{G})$ positioned at 31 amino acid resulted in missense mutation from aspartic acid to asparagine residue. This is the first report of HSP (HSP16.9) derived SNP marker associated with terminal heat stress in wheat.

Aryal et al., (2013) elucidated the response of twenty drought tolerant wheat genotypes to different dates of sowing and found the significant reduction in grain yield under late sown that was exposed to terminal heat stress.

Hossain et al., (2013) evaluated eight spring wheat cultivars under three heat stress conditions (early, late and very late) in order to identify suitable cultivars to develop heat tolerant genotypes resistant to future global warming. Results from the study indicate that BARI Gom-26, Shatabdi and Sufi have the greatest potential to be used as high-yielding wheat genotypes under warm to hot environments and could be used in a breeding programme to develop heat-tolerant wheat genotypes.

Mondal et al., (2013) explained Canopy Temperature Depression (CTD) was positively associated with grain yield, thereby suggesting that cooler canopies may contribute to higher grain yield under normal as well as high temperature stress conditions.

Pandey (2013) utilized difference in grain filling rate between the timely and late sown conditions as a phenotypic parameter to find association with molecular markers in a set of 111 RILs derived from Raj 4014, a heat sensitive genotype and WH 730, heat tolerant cultivar using with 300 SSR markers out of which $15 \%$ (45) were polymorphic between parental lines. Using these polymorphic 
markers they found significant association of dGFR of RILs with two markers viz., Xbarc04 and Xgwm314 with coefficients of determination $\left(\mathrm{R}^{2}\right)$ values of 0.10 and 0.06 , respectively through regression analysis.

Pandey et al., (2014) evaluated mapping population (RILs) and screened parental lines with approximately 300 SSR markers out of which about $20 \%$ showed polymorphism which was eventually utilized for genotyping a subset that had clear contrasting variation for difference in thousand grain weight between the timely and late sown conditions. With Regression analysis they found significant association of difference in thousand grain weight of RILs with two markers viz., Xpsp3094 and Xgwm282 with coefficients of determination $\left(\mathrm{R}^{2}\right)$ values of 0.14 and 0.11 , respectively.

Pinto and Reynolds (2015) studied common genetic basis for canopy temperature depression under heat and drought stress, associated with optimized root distribution in bread wheat. Under water stress, the cool genotypes showed a deeper root system allowing the extraction of $35 \%$ more water from the $30-90 \mathrm{~cm}$ soil profile. The strategy under heat was to concentrate more roots at the surface, in the $0-60 \mathrm{~cm}$ soil layer where water was more available from surface irrigation. Since cool genotypes showed better agronomic performance, they concluded that their QTL are associated with more optimal root distribution in accordance with water availability under the respective stresses.

Sharma et al., (2015) explained that wheat genotypes differed significantly in their response to high temperature. Among 25 SSCP variants detected in HSP 16.9 targeted coding sequence, 12 were polymorphic and three of them were found significantly associated with canopy temperature (CT), relative water content (RWC), thousand grain weight (TGW) and normalized difference vegetation index (NDVI). These associated alleles explained range 11.4 to $32.9 \%$ of the variation for individual trait. The association between HSP variants and these traits may provide new insight for HSPs potential contribution to thermo-tolerance which can be used for improvement of thermo-tolerance in wheat through marker assisted selection.

List of QTLs identified for heat tolerance mentioned in tables 1, 2, 3 and 4. Hence, with this information robust QTLs can be choosen and introgressed into an elite variety and screening of breeding material can be done using robust marker tightly linked with heat tolerance for crop improvement.

Desirable traits for measuring the heat tolerance in wheat (Kumar et al., 2013)

\section{Yield traits}

Plot yield (Fisher et al., 1998)

Thousand grains weight (Shpiler and Blum, 1991)

Grain filling duration (Randall and Moss, 1990)

Number of effective tillers per plant (Richards, 1996)

\section{Morphological traits}

Early ground cover (Richards, 1996)

Stay green (Zhao et al., 2007)

Epicuticular wax/leaf glaucousness (Richards, 1996)

Leaf rolling (Araus, 1996)

Biomass (Reynolds et al., 2001)

\section{Physiological traits}

Canopy temperature (Reynolds et al., 1994)

Photosynthetic rate (Rijven, 1986)

Chlorophyll content (Al-Khatib and Paulsen, 1984) 
Chlorophyll fluorescence (Azam et al., 2015)

Stomata conductance (Reynolds et al., 1994)

Stem reserve (Mohammadi et al., 2009)

Membrane thermostability (Shanahan et al., 1990).

\section{Insight into Important Criteria for Heat Stress Tolerance}

\section{Grain filling duration (GFD)}

Grain filling duration can be calculated using the difference between the date of anthesis and physiological maturity (when the peduncle turns to yellow). The phenotypic selection using indirect selection parameters viz., grain filling duration (Yang et al., 2002b) for heat tolerance has been done.

\section{Canopy Temperature Depression (CTD)}

Developing cultivars with improved adaptation to drought and heat stressed environments is a priority for plant breeders. Canopy temperature is a useful tool for phenotypic selection of tolerant genotypes, as it integrates many physiological responses into a single low-cost measurement (Mason and Singh, 2014). CTD has shown clear association with yield in warm environments shows it association with heat stress tolerance. CTD shows high with yield and high values of proportion of direct response to selection (Reynolds et al., 1998). Canopy temperature can be recorded on each plot (4 rows) using a handheld infrared thermometer on bright sunny days between 1 and 3 pm. For each plot, measurements were made at approximately $0.5-1 \mathrm{~m}$ distance from the edge of the plot and approximately $50 \mathrm{~cm}$ above the canopy with an approximate angle of $30^{\circ}$ $60^{\circ}$ from horizontal giving a canopy view of $10 \mathrm{~cm} \times 25 \mathrm{~cm}$ (Ayeneh et al., 2002). CTD calculated using the following formula:

CTD = Ambient temperature - Canopy temperature
Where, ambient temperatures will be measured in each plot, using a handheld thermometer.

The phenotypic selection using indirect selection parameters, canopy temperature depression (Ayeneh et al., 2002; Reynolds et al., 1994; 2001) for heat tolerance has been done. Genotypes having cooler canopies (higher CTD) showed longer grain filling period and consequently maintained less reduction of 1000-grain weight under heat stress condition. Late planting potential can be understood by higher canopy temperature depression during post anthesis heat stress condition which might be used as selection criteria (Ray and Ahmed, 2015).

\section{Stomatal conductance}

No doubt canopy temperature depression is a very important criteria for heat tolerance, however in high humidity area, observing stomatal conductance will be fruitful. Because, leaves maintain their stomata open to permit the uptake of $\mathrm{CO}_{2}$ and differences in the rate of $\mathrm{CO}_{2}$ fixation may lead to differences in leaf conductance that can be measured using a porometer.

\section{0- Grain weight}

The phenotypic selection using indirect selection parameters viz., thousand grain weight (Sharma et al., 2008) for heat tolerance has been done.

\section{Membrane thermostability}

In presence of heat stress membrane will be affected severely. Hence checking membrane thermostability by measuring solute leakage from tissue is good estimate to membrane damage. Fokar et al., 1998 also states that membrane thermostability is heritable and shows high genetic correlation with yield. 


\section{Chlorophyll fluorescence}

Chlorophyll fluorescence represents a very small fraction of the energy that is dissipated from the photosynthetic mechanism, but it is widely used to provide information about the structure and function of the electron transport chain (Strasser et al., 2004). Plants exposed to high temperatures exhibit two opposite effects in the electron transport chain of photosynthesis. Photosystem I (PSI) is stimulated by heat (as measured by the rate of $\mathrm{P} 700^{+}$reduction) due to greater reduction of the plastoquinone (PQ) pool by ferredoxin (Fd) at high temperatures (Tóth et al., 2007). In contrast, photosystem II (PSII), particularly the oxygen-evolving complex, is deactivated even at slightly elevated temperatures (Yamane et al., 1998), demonstrating that this process is especially sensitive to temperature stress (Pushpalatha et al., 2008).

Table.1 QTL related to the grain filling rate as indicator for heat tolerance genes in the 162 F2 plants population of Debra X Yecora Rojo (Barakat et al., 2011)

\begin{tabular}{|l|c|c|c|c|}
\hline Markers & QTL $(\mathbf{c M})$ & Chromosome & LOD & $\mathbf{R}^{\mathbf{2}}(\boldsymbol{\%})$ \\
\hline Xgwm132-6A & 36.6 & $6 \mathrm{~A}$ & 6.3 & 7.0 \\
\hline Xgwm577-6B & 6.1 & $6 \mathrm{~B}$ & 50.4 & 25.0 \\
\hline Xgwm617-7D & 17.1 & 7D & 23.9 & 3.3 \\
\hline
\end{tabular}

Table.2 QTLs for heat stress tolerance (Ali et al., 2013)

\begin{tabular}{|l|l|l|l|l|l|l|}
\hline Trait & QTL & Chromosome & Marker & $\begin{array}{l}\text { Map } \\
\text { distance } \\
(\mathbf{c M})\end{array}$ & LOD & $\mathbf{R}^{2}$ \\
\hline $\begin{array}{l}\text { Chlorophyll content } \\
\text { at 4DPA }\end{array}$ & QChlc.tamu-1B & $1 \mathrm{~B}$ & Xbarc128 & 18 & 8.0 & 22.5 \\
\hline $\begin{array}{l}\text { Chlorophyll content } \\
\text { at 8DPA }\end{array}$ & QChlc.tamu-1B & $1 \mathrm{~B}$ & Xbarc128 & 18 & 6.0 & 45.3 \\
\hline $\begin{array}{l}\text { Flag leaf } \\
\text { temperature } \\
\text { depression at 4DPA }\end{array}$ & QFlt.tamu-2B & 2B & Xbarc10 & 43 & 4.5 & 11.0 \\
\hline $\begin{array}{l}\text { Flag lag } \\
\text { temperature leaf } \\
\text { depression at 8DPA }\end{array}$ & QFlt.tamu-2B & 2B & Xbarc10 & 43 & 4.5 & 43.8 \\
\hline $\begin{array}{l}\text { Individual kernel } \\
\text { weight }\end{array}$ & QIkw.tamu-5A & 5A & Xgwm205 & 32 & 4.0 & 60.1 \\
\hline
\end{tabular}


Table.3 QTLs for heat stress tolerance in NW1014 (heat tolerant) $\times$ HUW468 (heat susceptible) RILs population (Paliwal et al., 2012)

\begin{tabular}{|c|c|c|c|c|c|}
\hline Traits/QTLs & Marker interval & $\begin{array}{l}\text { Interval } \\
\text { size }(\mathrm{cM})\end{array}$ & Chromosome & LOD & $\%$ PVE \\
\hline $\begin{array}{l}\text { TGW } \\
\text { QHthsitgw.bhu-2B } \\
\text { QHthsitgw.bhu-7B } \\
\text { QHthsitgw.bhu-7D }\end{array}$ & $\begin{array}{l}\text { Xgwm935-Xgwm1273 } \\
\text { Xgwm1025-Xgwm745 } \\
\text { Xgwm3062-Xgwm4335 }\end{array}$ & $\begin{array}{l}23.0 \\
3.6 \\
3.1\end{array}$ & $\begin{array}{l}\text { 2BL } \\
7 \mathrm{BL} \\
7 \mathrm{DS}\end{array}$ & $\begin{array}{l}3.4 \\
8.7 \\
3.5\end{array}$ & $\begin{array}{l}17.82 \\
20.34 \\
9.78\end{array}$ \\
\hline $\begin{array}{l}\text { YLD } \\
\text { QlsYLD.bhu-7B }\end{array}$ & Xgwm1025-Xgwm745 & 3.6 & $7 \mathrm{BL}$ & 4.4 & 13.21 \\
\hline $\begin{array}{l}\text { GFD } \\
\text { QHthsigfd.bhu-2B }\end{array}$ & Xgwm935-Xgwm1273 & 23.0 & $2 \mathrm{Bl}$ & 3.1 & 20.15 \\
\hline $\begin{array}{l}\text { CTD } \\
\text { QHtctd.bhu-7B }\end{array}$ & Xgwm1025-Xgwm745 & 3.6 & $7 \mathrm{BL}$ & 6.9 & 19.81 \\
\hline
\end{tabular}

Table.4 QTLs associated with high temperature tolerance mapped in the cv. Berkut $\times \mathrm{cv}$. Krichauff Double haploid population using heat susceptibility index (Tiwari et al., 2013)

\begin{tabular}{|l|l|l|l|l|l|}
\hline Traits/QTL & Marker interval & $\begin{array}{l}\text { Interval } \\
\text { size }(\mathbf{c M})\end{array}$ & Chromosome & LOD & \% PVE \\
\hline $\begin{array}{l}\text { HSIGY } \\
\text { QHY.bhu-1DL }\end{array}$ & wmc216-cfd19 & 2.4 & $1 \mathrm{DL}$ & 2.2 & 10.24 \\
\hline $\begin{array}{l}\text { HSITGW } \\
\text { QHTgw.bhu-1DS }\end{array}$ & wPt9664-cfd083 & 13.8 & $1 \mathrm{DS}$ & 2.6 & 11.76 \\
QHTgw.bhu-6BL & & 3.0 & $6 \mathrm{BL}$ & 3.0 & 13.97 \\
\hline $\begin{array}{l}\text { HSIGFD } \\
\text { QHGfd.bhu1-2DL }\end{array}$ & gwm349-wPt9797 & 5.1 & $2 \mathrm{DL}$ & 4.5 & 21.01 \\
$\begin{array}{l}\text { QHGfd.bhu2-2DL } \\
\text { HGfd.bhu1-7AL }\end{array}$ & wmc065-wmc139 & 2.2 & 2DL & 4.5 & 20.60 \\
\hline $\begin{array}{l}\text { HSICT } \\
\text { QHCt.bhu-1DS }\end{array}$ & wPt9664-cfd083 & 0.7 & $1 \mathrm{DL}$ & 2.7 & 12.27 \\
\hline
\end{tabular}

\section{Stay green}

Stay-green is the term given to a variant in which senescence is delayed in comparison to a standard reference genotype (Thomas and Howarth, 2000; Joshi et al., 2007). Abiotic stress tolerance is a major feature of staygreen genotypes, giving stability to grain yield even in unfavourable environmental conditions (Luche et al., 2015). Maintenance of grain filling in the last stage of plant maturity has been considered as key to the success of stay-green genotypes.

\section{Susceptibility indices}

Susceptibility Indices for some trait based on the formula given by Fischer and Maurer (1978) will be calculated using formula mentioned below E.g. for heat stress it will be calculated as: 
Susceptibility Index (SI) of $X=\left[\left(1-X_{\text {stress }} / X\right.\right.$ control)/D]

Where,

$X=$ Trait of interest

$\mathrm{X}_{\text {stress }}=\mathrm{X}$ in heat stress environment

$\mathrm{X}_{\text {control }}=\mathrm{X}$ in control environment

$\mathrm{D}$ (stress Intensity) $=\left(1-\mathrm{X}^{\text {stress }} / \mathrm{X}^{\text {control }}\right)$

$X^{\text {stress }}=$ Mean of $X^{\text {stress }}$ of all genotypes

$\mathrm{X}^{\text {control }}=$ Mean of $\mathrm{X}^{\text {control }}$ of all genotypes

In conclusion, heat is a staple food crop of India, which is unavoidable from the diets of Indian population. However this crop is severely affected by heat stress. To feed the increasing population it will become compulsory to breed the promising genotypes for heat stress tolerance. To do this, understanding the mechanism/genetics of heat stress problem and criteria to measure this is an important strategy and need of the time. Hence, this review will provide the information about the wheat heat stress, its affect to yield loss, linked genes/QTLs or molecular markers available till date and how to combat to climate change. In the era of climate change incorporating the marker assisted selection is an efficient breeding strategy. Identified genomic region will play an important role for further crop improvement in terms of introgression of heat tolerant QTLs into an elite variety or pyramiding of all heat tolerant genes into an agronomically superior variety/genotype. Canopy temperature depression, thousand grain weight, membrane thermostability, stomatal conductance, chlorophyll fluorescence and stay green trait are an important criteria for crop improvement against heat stress or terminal heat stress..

\section{Abbreviations}

QTL-Quantitative Trait Loci

SNP-Single Nucleotide Polymorphism

RIL-Recombinant Inbred Line

CIMMYT-International Maize and Wheat Improvement Center
IPCC-Intergovernmental Panel on Climate Change

SSCP-Single-Strand Conformation

Polymorphism or Single-Strand Chain

Polymorphism

CT-Canopy Temperature

RWC-Relative Water Content

TGW-Thousand Grain Weight

NDVI-Normalized Difference Vegetation

Index

HSI-Heat Susceptibility Index

\section{References}

Ali, M.B., Ibrahim, A.M.H., Malla, S., Rudd, J. and Hays, D.B. 2013. Family-based QTL mapping of heat stress tolerance in primitive tetraploid wheat (Triticum turgidum L.). Euphytica, 192(2): 189-203.

Al-Khatib, K. and Paulsen, G. M. 1984. Mode of high temperature injury to wheat during grain development. Plant Physiol., 61: 363-368.

Anonymous. 2015a. United States Department of Agriculture, World Agricultural Production, Foreign Agricultural Service, Circular Series, WAP 11-15, November 2015.

Anonymous. 2015b. Indian institute of Wheat and Barley Research, Karnal, Progress Report 2014-15.

Araus, J.L. 1996. Integrative physiological criteria associated with yield potential. In: Reynolds MP, Rajaram S, McNab A (eds. Increasing yield potential in wheat: breaking the barriers. Workshop Proc., Cd. Obregon, Mexico, 28-30 Mar. 1996, Mexico, DF, CIMMYT, pp 150166.

Aryal, L., Shrestha, S. M., and G.B.K.C. 2013. Effect Of Date Of Sowing On The Performance Of Drought Tolerant Wheat Genotypes To Spot Blotch At Rampur, Chitwan, Nepal, Int. J. Appl. Sci. Biotechnol., Vol. 1(4): 266-271 DOI: 10.3126/ijasbt.v1i4.9180.

Ayeneh, A., Ginkel, M., Reynolds, M. P. and Ammar, K. 2002. Comparison of leaf, spike, peduncle, and canopy temperature 
depression in wheat under heat stress. Field Crops Res., 79: 173184.

Azam, F.I., Chang, X. and Jing, R. 2015. Mapping QTL for chlorophyll fluorescence kinetics parameters at seedling stage as indicators of heat tolerance in wheat. Euphytica, 202: 245258 DOI 10.1007/s10681-014-1283-1.

Barakat, M. N., Al-Doss, A. A., Elshafei, A. A. and Moustafa, K. A. 2011. Identification of new microsatellite marker linked to the grain filling rate as indicator for heat tolerance genes in $\mathrm{F}_{2}$ wheat population. Australian J. Crop Sci., 5(2): 104-110.

Fischer, R.A. and Byerlee, D.B. 1991. Trends of wheat production in the warmer areas: major issues and economic considerations. In: Wheat for the Nontraditional Warm Areas. Proc. of Conf., Iguazu, Brazil, 29 Jul.-3 Aug. 1990. CIMMYT, Mexico, DF. pp 3-27.

Fischer, R.A. and Maurer, R. 1978. Drought resistance in spring wheat cultivars: grain yield responses. Aust. J. Agric. Res., 29: 897-907.

Fisher, R. A., Rees, D., Sayre, K. D., Lu, Z. M., Condon, A. G. and Savedra, A. L. 1998. Wheat yield progress associated with higher stomatal conductance and photosynthetic rate, and cooler canopies. Crop Sci., 38: 1467-1475.

Fokar, M., Nguyen, H.T. and Blum A. 1998. Heat tolerance in spring wheat. I. Genetic variability and heritability of cellular thermotolerance. Euphytica, 104: 1-8.

Furbank, R.T. and Tester, M. 2011. Phenomicstechnologies to relieve the phenotyping bottleneck. Trends Plant Sci., 16: 1-10.

Garg, D., Sareen, S., Dalal, S., Tiwari, R. and Singh, R. 2012. Heat shock protein based SNP marker for terminal heat stress in wheat (Triticum aestivum L. AJCS, 6(11): 1516-1521.

Gupta, P.K., Mir, R.R., Mohan, A. and Kumar, J. 2008. Wheat Genomics: Present Status and Future Prospects Hindawi Publishing Corporation. Int. J. Plant Genomics, doi:10.1155/2008/896451.

Hays, D., Mason, E., Hwa, Do, J., Menz, M. and Reynolds, M. 2007. Expression quantitative trait loci mapping heat tolerance during reproductive development in wheat ( $\mathrm{T}$. aestivum). In: Buck HT, Nisi JE, Salomo'n N (eds. Wheat production in stressed environments. Springer, Amsterdam, pp 373-382.

Hossain, C.A., Sarkera, M.A.Z., Saifuzzamana, M., Teixeira da Silvab, J.A., Lozovskayac, M.V. and Akhtera M.M. 2013. Evaluation of growth, yield, relative performance and heat susceptibility of eight wheat (Triticum aestivum L.. genotypes grown under heat stress, Int. J. Plant Production, 7(3): (Online. www.ijpp.info.

Howard, A. 1924. Crop production in India: a critical survey of its problems. Oxford University Press, Oxford, UK, p 156.

IPCC Climate change. 2007. The physical science basis. In: Solomon, S., Qin, D.,Manning, M., Chen, Z., Marquis, M., Averyt, K.B., Tignor, M., Miller, H. Eds.), Contribution of Working Group I to the Fourth Assessment Report of the Inter-governmental Panel on Climate Change. Cambridge University Press, Cambridge, UK, New York, USA.

Joshi, A.K., Ortiz-Ferrara, G., Crossa, J., Singh, G., Sharma, R.C., Chand, R. and Parsad, R. 2007. Combining superior agronomic performance and terminal heat tolerance. Field Crops Res., 103(1): 53-61.

Joshi, A.K., Chand, R., Arun, B., Singh, R.P. and Ortiz, R, (2007a. Breeding crops for reduced-tillage management in the intensive, rice-wheat systems of South Asia. Euphytica, 153: 135-151.

Kato, K., Miura, H. and Sawada, S. 2000. Mapping QTLs controlling grain yield and its components on chromosome 5A of wheat. Theor. Appl. Genet., 101; 11141121.

Kumar, S., Kumari, P., Kumar, U., Grover, M., Singh, A.S., Singh, R. and Sengar, R. S. 2013. Molecular approaches for designing heat tolerant wheat. J. Plant Biochem. Biotechnol., DOI 10.1007/s13562-013- 
0229-3.

Luche, Henrique de Souza, Silva, José Antonio Gonzalez da, Maia, Luciano Carlos da; Oliveira, Antonio Costa de. 2015. Staygreen. A potentiality in plant breeding. In Cienc. Rural, 45(10), pp. 1755-1760.

Mason, R. E., Mondal, S., Beecher, F. W., Pacheco, A., Jampala, B., Ibrahim, A. M. H. and Hays, D. B. 2010. QTL associated with heat susceptibility index in wheat (Triticum aestivum L. under short-term reproductive stage heat stress. Euphytica, 174: 423-436.

Mason, R. E. and Singh, R. P. 2014. Considerations When Deploying Canopy Temperature to Select High Yielding Wheat Breeding Lines under Drought and Heat Stress. Agron., 4: 191-201.

Mohammadi, V., Qannadha, M. R., Zali, A.A. and Yazdi-Samadi, B. 2004. Effects of post-anthesis heat stress on the head traits of wheat. Int. J. Agri. Biol., 6(1): 42-44. 20.

Mohammadi, V., Zali, A.A. and Bihamta, M.R. 2008. Mapping QTLs for heat tolerance in wheat. J. Agric Sci. Technol., 10: 261267.

Mohammadi, M., Karimizadeh, R.A. and Naghavi, M.R. 2009. Selection of bread wheat genotypes against heat and drought tolerance on the base of chlorophyll content and stem reserves. J. Agric. Soc. Sci., 5: 119-122.

Mondala, S., Singha, R.P., Crossaa, J., HuertaEspinoa, J., Sharmac, I., Chatrathc, R., Singhd, G.P., Sohue, V.S., Mavie, G.S., Sukaruf, V.S.P., Kalappanavargg, I.K., Mishrah, V.K., Hussaini, M., Gautamj, N.R., Uddink, J., Barmak, N.C.D., Hakimk, A. and Joshi, A.K. 2013. International Earliness in wheat: A key to adaptation under terminal and continual high temperature stress in South Asia Field Crops Res., 151: 19-26.

Moshatati, A., Siadat, S.A., Alami Saeid, Kh., Bakhshandeh, A.M., Andm, R. and Jalal K. 2012. Effecct of terminal heat stress on yield and yield componenets of spring bread wheat cultivars in Ahwaz, Iran. Int.
J. Agri. Res. Rev., Vol., 2(6): 844-849.

Nagarajan, S. 2005. Can India produce enough wheat even by 2020? Curr. Sci., 89: 1467-1471.

Ortiz, R., Sayre, K. D., Govaerts, B., Gupta, R., Subbarao, G. V., Ban, T.O., Hodson, D., Dixon, J. M., Ortiz-Monasterio, J. I. and Reynolds, M. 2008). Climate change: Can wheat beat the heat? Agric. Ecosys. Environ., 126: 46-58.

Paliwal, R., Röder, M.S., Kumar, U., Srivastava, J.P. and Joshi, A.K. 2012). QTL mapping of terminal heat tolerance in hexaploid wheat (T. aestivum L.). Theor. Appl. Genet., 125: 561-575.

Pandey, G.C., Rane, J., Sareen, S., Siwach, P., Singh, N.K. and Tiwari, R. 2013. Molecular investigations on grain filling rate under terminal heat stress in bread wheat (Triticum aestivum L.). African J. Biotechnol., 12(28): 4439-4445.

Pandey, G.C., Sareen, S., Siwach, P. and Tiwari, R. 2014. Molecular characterization of heat tolerance in bread wheat (Triticum aestivum L.. using differences in thousand-grain weights (dTGW. as a potential indirect selection criterion. Cereal Res. Communications, 42(1): 38-46.

Patil, R.V., Viswanathan Chinnusamy, Shakti Chauhan, Ruwali, K. N., Pandey, H. N. and Chopra, R.K. 2008. Evaluation of heat stress tolerance in $\mathrm{T}$. aestivum and $\mathrm{T}$. durum wheat genotypes under continual and terminal heat stress environments. $J$. Plant Biol., 35(1): 1-16.

Patterson, A.H. 1998. Molecular Dissection of Complex Traits, CRC Press, New York, pp. 1998.

Pinto, R.S., Reynolds, M.P., Mathews, K.L., McIntyre, C.L., Olivares-Villegas, J. and Chapman, S.C. 2010. Heat and drought adaptive QTL in a wheat populationdesigned to minimize confounding agronomic effects. Theor. Appl. Genet., 121: 1001-1021.

Pinto, R.S. and Reynolds, M.P. 2015. Common genetic basis for canopy temperature depression under heat and drought stress 
associated with optimized root distribution in bread wheat, Theor. Appl. Genet., 128: 575-585, DOI 10.1007/s00122-015-2453-9.

Rane, J., Shoran, J. and Nagarajan, S. 2000. Heat stress environments and impact on wheat productivity in India: Guestimate of losses. Indian Wheat News Lett., 6(1): 5- 6.

Randall, P.J. and Moss, H.J. 1990. Some effects of temperature regime during grain filling on wheat quality. Aus. J. Agricul. Res., 41: 603-617.

Ray, J. and Ahmed, J.U. 2015. Canopy Temperature Effects on Yield and Grain growth of Different Wheat Genotypes. IOSR J. Agri. Vet. Sci., 8(7): 2319-2380.

Richards, R. A. 1996. Defining selection criteria to improve yield under drought. Plant Grow Reg., 20:157-166.

Reynolds, M. P., Balota, M., Delgado, M.I.B., Amani, J. and Fischer, R.A. 1994).Physiological and morphological traits associated with spring wheat yield under hot, irrigated conditions. Aust. J. Plant Physiol. 21: 717-730.

Reynolds, M. P., Singh, R. P., Ibrahim, A., Ageeb, O. A., Larqué-Saavedra, A. and Quick, J. S. 1998. Evaluating physiological traits to compliment empirical selection for wheat in warm environments. Euphytica, 100: 85-94.

Reynolds, M. P., Nagarajan, S., Razzaque, M. A., Ageeb, O. A. A. 2001. Heat tolerance. In: Reynolds MP, Ortiz-Monasterio I, McNab A (eds. Application of physiology in wheat breeding. CIMMYT, Mexico, DF.

Reynolds, M.P. and Borlaug, N.E. 2006. International collaborative wheat improvement: impacts and future prospects. J. Agric. Sci., 144: 3-17.

Reynolds, M. P., Hobbs, P.R. and Braun, H.J. 2007. Challenges to international wheat improvement. J. Agric. Sci., 145, 223 227.

Rijven, A. H. G. 1986. Heat inactivation of starch synthase in wheat endosperm. Plant Physiol., 81: 448-453.
Singha, P., Bhowmick, J., and Chaudhury, B. K. 2006. Effect of temperature on yield and yield components of fourteen wheat (Triticum aestivum L.. genotypes. Environ. Ecol. 24: 550-554.

Shanahan, J. F., Edwards, I. B., Quick J. S. and Fenwick, J. R. 1990. Membrane thermostability and heat tolerance of spring wheat. Crop Sci., 30:247-251.

Sharma, S. N., Bhatnagar, V. K., Mann, M. S., Shekhawat, U. S. and Sain, R. S. 2002. Maximization of wheat yields with a unique variety in warmer areas. Wheat Inform Ser., 95: 11-16.

Sharma, R. C., Tiwari, A. K. and Ortiz-Ferrara, G. 2008. Reduction in kernel weight as a potential indirect selection criterion for wheat grain yield under heat stress. Plant Breed, 127: 241-248.

Sharma, D., Mamrutha, H. M., Gupta, V.K., Tiwari, R. and Singh, R. 2015. Association of SSCP variants of HSP genes with physiological and yield traits under heat stress in wheat, Res. on Crops, 16(1): 139-146.

Shpiler, L. and Blum, A. 1991. Heat tolerance for yield and its components in different wheat cultivars. Euphytica, 51: 257-263.

Singh, B.D. and Singh, A.K. 2015. MarkerAssisted Plant Breeding: Principles and Practices. Springer publication, page no. 217-255. DOI 10.1007/978-81-322-23160.

Singh, R.P., Huerta-Espino, J., Sharma, R. C., Joshi, A. K. and Trethowan, R. 2007. High yielding spring wheat germplasm for global irrigated and rainfed production systems. Euphytica, 157: 351-363.

Singh, K., Sharma, S. N. and Sharma, Y. 2011. Effect of high temperature on yield attributing traits in bread wheat, Bangladesh J. Agril. Res., 36 (3): 415426.

Singh, R.P. and Trethowan, R. 2007. Breeding spring bread wheat for irrigated and rainfed production systems of the developing world. In: Kang, M., Priyadarshan, P. M. Eds.), Breeding Major Food Staples. Blackwell Publishing, Iowa, USA, 
pp.109-140.

Tandon, J.P. 1994. Wheat cultivation, research organization and production technology in the hot dry regions of India. In: Saunders DA, Hettel GP (eds. Wheat in heat-stressed environments: irrigated, dry areas and rice-wheat farming systems. CIMMYT, Mexico, DF, pp 17-23.

Thomas, H. and Howarth, C. J. 2000. Five ways to stay green. J. Experimental Bot., v.51, 329-337.

Tiwari, C., Wallwork, H., Uttam Kumar, Ram Dhari, Arun, B. Mishra, V. K. Reynolds, M. P. and Joshi, A.K. 2013. Molecular mapping of high temperature tolerance in bread wheat adapted to the Eastern Gangetic Plain region of India. Field Crops Res., 154:201-210.

Tyagi, P.K., Pannu, R. K., Sharma, K. D., Chaudhary, B. D., and Singh, D. P. 2003. Response of different wheat (Triticum aestivum L.. cultivars to terminal heat stress. Tests Agrochem. Cultivars, 24: 20-
21.

Vijayalakshmi, K., Fritz, A. K., Paulsen, G. M., Bai, G., Pandravada, S., and Gill, B. S. 2010. Modeling and mapping QTL for senescence-related traits in 1250 winter wheat under high temperature. Mol. Breed., 26: 163-175.

Yang, J., Sears, R.G., Gill, B.S. and Paulsen, G.M. 2002. Quantitative and molecular characterization of heat tolerance in hexaploid wheat. Euphytica, 126: 275282.

Yang, J, Sears, R. G., Gill, B. S. and Paulsen, G. M. 2002b. Quantitative and molecular characterization of heat tolerance in hexaploid wheat. Euphytica, 126: 275282.

Zhao, H., Tingbo, D., Qi, J., Dong, J. and Weixing, C. 2007. Leaf senescence and grain filling affected by post-anthesis high temperatures in two different wheat cultivars. Plant Growth Reg., 51: 149158.

\section{How to cite this article:}

Kailash Chandra, Ravindra Prasad, Padma Thakur, Kuduka Madhukar and Prasad, L.C. 2017. Heat Tolerance in Wheat - A Key Strategy to Combat Climate Change through Molecular Markers. Int.J.Curr.Microbiol.App.Sci. 6(3): 662-675. doi: https://doi.org/10.20546/ijcmas.2017.603.077 